IZA DP No. 4425

Immigrants and Employer-Provided Training

Alan Barrett

Séamus McGuinness

Martin O'Brien

Philip O'Connell

September 2009 


\title{
Immigrants and Employer-Provided Training
}

\author{
Alan Barrett \\ Economic and Social Research Institute \\ and IZA \\ Séamus McGuinness \\ Economic and Social Research Institute \\ Martin O'Brien \\ Economic and Social Research Institute \\ Philip O'Connell \\ Economic and Social Research Institute
}
Discussion Paper No. 4425
September 2009

\author{
IZA \\ P.O. Box 7240 \\ 53072 Bonn \\ Germany \\ Phone: $+49-228-3894-0$ \\ Fax: +49-228-3894-180 \\ E-mail: iza@iza.org
}

\begin{abstract}
Any opinions expressed here are those of the author(s) and not those of IZA. Research published in this series may include views on policy, but the institute itself takes no institutional policy positions.

The Institute for the Study of Labor (IZA) in Bonn is a local and virtual international research center and a place of communication between science, politics and business. IZA is an independent nonprofit organization supported by Deutsche Post Foundation. The center is associated with the University of Bonn and offers a stimulating research environment through its international network, workshops and conferences, data service, project support, research visits and doctoral program. IZA engages in (i) original and internationally competitive research in all fields of labor economics, (ii) development of policy concepts, and (iii) dissemination of research results and concepts to the interested public.
\end{abstract}

IZA Discussion Papers often represent preliminary work and are circulated to encourage discussion. Citation of such a paper should account for its provisional character. A revised version may be available directly from the author. 
IZA Discussion Paper No. 4425

September 2009

\section{ABSTRACT}

\section{Immigrants and Employer-Provided Training*}

Much has been written about the labour market outcomes for immigrants in their host countries, particularly with regard to earnings, employment and occupational attainment. However, much less attention has been paid to the question of whether immigrants are as likely to receive employer-provided training relative to comparable natives. As such training should be crucial in determining the labour market success of immigrants in the long run it is a critically important question. Using data from a large scale survey of employees in Ireland, we find that immigrants are less likely to receive training from employers, with immigrants from the New Member States of the EU experiencing a particular disadvantage. The immigrant training disadvantage arises in part from a failure on the part of immigrants to get employed by training-oriented firms. However, they also experience a training disadvantage relative to natives within firms where less training is provided.

JEL Classification: J24, J61

Keywords: immigrants, employer-provided training, Ireland

Corresponding author:

Alan Barrett

Economic and Social Research Institute

Whitaker Square

Sir John Rogerson's Quay

Dublin 2

Ireland

E-mail: Alan.Barrett@esri.ie

\footnotetext{
* We would like to acknowledge the funding provided by the Irish Research Council for the Humanities and Social Sciences under the Government of Ireland Thematic Research Project Grants Scheme.
} 


\section{Section 1: Introduction}

Much has been written about the labour market outcomes of immigrants across countries and over time. Studies often find that immigrants experience labour market disadvantages relative to natives soon after arrival in their host countries (Chiswick, 1978). Such disadvantages are seen through lower wages or higher unemployment propensities for immigrants, usually controlling for relevant labour-market characteristics of individuals. Some studies show reductions in the relative disadvantage of immigrants as they spend longer in their host countries (Chiswick, Lee and Miller, 2005). Other studies show persistence in disadvantages (Borjas, 1985).

Other aspects of the experience of immigrants in their host country labour markets have generally received less attention. In this paper, we aim to contribute to addressing this by conducting an analysis of the extent to which immigrants receive employer-provided training, relative to comparable natives. Given the importance of such training in facilitating immigrants to fully integrate into host country labour markets, any findings of lower access to training for immigrants would have important implications. For example, it could be that a persistence of any initial earnings disadvantage for immigrants could be related in part to a failure to benefit from employer-provided training.

The paper is structured as follows. In Section 2, we provide a brief overview of the literature on the question of which employees are more likely to receive employerprovided training. We will also provide details of the limited work on immigrants and training. In Section 3, we present details of the data that we use to analyse our core question, namely, are immigrants more or less likely to receive employer-provided training. In Section 4, we present our results. As will be seen, we do find evidence of a lower incidence of training among immigrants, with interesting patterns emerging across different groups of immigrants. Section 5 contains our conclusions.

\section{Section 2: Literature}

O'Connell and Junglut (2008) in their review of the international literature, argue that participation in training at work is highly stratified. Those with higher skills or 
educational attainment are more likely to participate in training, including employerprovided training. Larger firms and those that pay higher wages are also more likely to train their employees. Part-time workers, those on temporary contracts and older workers are less likely to receive training. O’Connell and Jungblut thus argue that those with the greatest need for training tend to receive less of it, presumably to their long-run disadvantage.

The dominant theoretical framework informing most research on training has been the human capital approach. This approach, deriving from Becker (1975), assumes that individual workers undertake training, and employers invest in training, on the basis of their estimates of future returns (including employment prospects, wages and productivity gains). The human capital approach emphasises the distinction between "general" training - of use to both current and future employers - and "specific" training, linked closely to the current job and of use only to the current employer. In this approach it is expected that employers will not pay for general training, because they cannot recoup the cost - other employers would be free to "poach" trained employees and reap the benefits of enhanced productivity. If, as a result of this market failure, employees have to pay the full cost of general training - whether directly or through reduced wages - it is likely that there will be under-investment in training.

However, empirical evidence tends not to support this hypothesis. The empirical literature has found that the theoretical distinction is difficult to operationalise and that many employers pay for both general and specific training. O’Connell and Jungblut (2008) summarise findings from Germany, Ireland, Sweden, the UK and the US that show that the vast majority of job-related training appears to be employer paid, at least partially. A growing stream of work challenges the human capital approach, focussing in particular on its key assumption that labour markets are perfectly competitive. If markets were perfectly competitive, workers with training would be more likely to move, and all workers would be treated similarly. One stream of work points to the importance of institutions - such as unions and labour market regulation (e.g. Acemoglu and Pischke, 1999). Booth, Francesconi and Zoega (2003) show that unions can have a positive or negative impact on training depending on union strategy and the manner in which unions negotiate on training and wages. 
For most workers in advanced industrial societies the employment contract entails an ongoing and relatively long-term relationship that may differ in important respects from the competitive labour market assumed in the Becker model (Barrett and O'Connell, 2001). This turns our attention to the demand side of the labour market and to the social organisation of work. The segmented labour market approach focuses more on the characteristics of jobs rather than individuals and argues that different labour market sectors impose structural limitations both on the returns to education and experience and on the career prospects of workers (Doeringer and Piore, 1971; Gordon, Edwards and Reich, 1982). At their simplest, labour market segments can be dichotomised, with the primary market consisting of well paid and secure employment as opposed to jobs in the secondary market which are poorly paid and are of a precarious nature with few or no prospects for upward mobility. From this perspective, workers in the secondary labour market are less likely to participate in job-related training, and the returns to such training are lower. Workers in the primary segment(s) are more likely to receive training, the returns are higher, and such training is likely to be associated with upward mobility, perhaps in an internal labour market.

We now turn to the literature that looks specifically at immigrants and their receipt of training relative to natives. We should firstly ask what theory will predict on the issue but in truth theory can point in either direction. As the human capital model views the issue of training in the context of the costs and benefits to both employees and employers, this allows us to identify some critical issues. For example, if immigrants see their stay in the host country as being temporary, they will be less inclined to invest in training which is specific in nature as the pay-off period will be restricted. Similarly, if employers believe that immigrant workers are more likely to leave, they will be less inclined to provide training. Alternatively, if training allows immigrants to acquire location-specific human capital that they are lacking, then the pay-off can be high.

If we are thinking in terms of segmented labour market theories (Doeringer and Piore, 1971), then predictions become more clear-cut. Under this theory, secondary labour 
markets are characterised by jobs which offer lower wages, fewer fringe benefits and poorer working conditions, including a lower incidence of training. If such secondary markets exist and if immigrants are more heavily concentrated in them, then immigrants will be less likely t be in receipt of training.

The empirical literature on the question of the relative receipt of employer-provided training across immigrants and natvies is thin, but three papers from Australia (Miller, 1994; Kennedy et al, 1994; Van den Heuvel and Wooden, 1997) point firmly in the direction of immigrants being less likely to receive training. This is especially true for immigrant groups with different linguistic backgrounds to the native population. Taking Van den Heuvel and Wooden (1997) as an example, they explore the issue using Australian data from 1993. By estimating logit regressions of training receipt, they show how immigrants in Australia from non-English speaking countries have lower incidences of training and that the gap relative to natives is more pronounced among immigrants from these countries who also report having weak English language skills.

Hum and Simpson (2003) look at the issue in Canada and also find a lower incidence of training among immigrants relative to natives. They go on to explore how training receipt among immigrants differs according to age at arrival in Canada. They show that training decreases with age of arrival and note that this is consistent with the argument that human capital acquired in the home country has a reduced value in the host country. Shields and Wheatley-Price (1999a and 1999b) look at differences by ethnic group, as opposed to immigrants, in the UK. They show that members of ethnic minorities are less likely to receive training, on average. One third of the difference can be explained by the characteristics of the individuals (in the case of men) but the remaining two-thirds cannot be explained by characteristics.

\section{Section 3: The Data}

The data used in this study comes from Ireland's National Employment Survey (NES) from March 2006. The 2006 NES is a workplace survey, covering both the public and private sectors, which was conducted by Ireland's official statistical office, Central 
Statistics Office (CSO $)^{2}$. The information contained in the NES was collected from a matched employee-employer survey. The employer sample was drawn using the CSO Central Business Register (CBR). Selected firms were asked to draw a systematic sample of employees from their payroll. Approximately 8,000 enterprises ${ }^{3}$ were contacted of which 4,845 responded resulting in employee information on 67,766 individuals. After the elimination of employees with information missing on some variables, part-time students and also the restriction of our sample to those of standard working age, the final sample for this study was just over 50,000 employees. When analysing the employee sample, cross-sectional weights were applied to ensure that the data was representative of the general population of employees in employment.

The employer questionnaire collected some limited information on firm size and sector that was incorporated into our models. Employees were issued with a separate survey within which they were asked to provide information on their age, gender, educational attainment, employment status (part-time or full-time), length of time in paid employment and also other job-related characteristics (for example, trade union membership, supervisory role, tenure with current employer).

Employees were also asked whether or not they had received employer-provided training during the course of the preceding year, 2005. They were asked a broad question about whether or not they had participated in any "company or company sponsored training courses in 2005”. They were also asked a more detailed question about types of training, such as training through participation in quality circles, job rotation etc. If an individual responded positively to any of the questions about participation in company training, we coded that person has having received employer-provided training. This is used as a binary dependent variable in the analysis below.

In terms of migration, each individual's country of origin was coded in a very detailed way that allowed us to separate out migrants into UK, Pre-accession EU (other than

\footnotetext{
${ }^{2}$ While the NES survey was of enterprises with 3 plus employees, the results were calibrated to the Quarterly National Household Survey (QNHS) employment data for employees (excluding agriculture, forestry and fishing), which covers all employees.

${ }^{3}$ Only employers with more than three employees were surveyed and the data were collected at the enterprise level.
} 
UK), New Member States of the EU (hereafter referred to as NMS) ${ }^{4}$, non-EU/English speaking and non-EU/non English speaking. The fact that the survey was conducted in March 2006 but that the training questions related to the year 2005 generated a concern that many immigrants would not have received training because they were very recent arrivals. In order to account for this, we excluded people who had entered zero in their response to the question on tenure and so we are only looking at individuals, both natives and migrants, with at least one year of tenure with their current employer. This restriction also has the advantage of removing any confusion surrounding individuals who changed jobs in early 2006 and who have answered the questions on training in 2005 with reference to their new employer.

\section{Section 4: Results}

In Table 1, we present some descriptive statistics showing how the incidence of participation in employer-provided training varies across groups. Of our sample of 50,154 individuals, almost 60 percent report participation in employer-provided training in 2005. There is essentially no difference in the incidence by gender. However, the likelihood of receiving increases by level of education. It is also the case that the incidence of training is higher among fulltime employees relative to parttime employees, among members of professional bodies relative to non-members and among union members relative to non-union. The incidence of training is also higher in the public sector relative to the private sector.

According to the raw data, immigrants are less likely to be in receipt of training relative to natives although the difference is not large. However, there is obviously a need to look at this issue in a multivariate context so that we can distil whether or not this small difference persists when controlling for other characteristics. We know from a series of papers that immigrants in Ireland are generally a highly educated group (see, for example, Barrett et al, 2006). For this reason, we might have expected them to have a higher incidence of training. In addition, we also know that immigrants from different regions have very different labour market experiences (Barrett and McCarthy, 2007). Hence, when undertaking multivariate analyses, we need to look across different immigrant groups as well as looking at immigrants as a whole.

\footnotetext{
${ }^{4}$ This refers to the 10 countries which joined the EU on 1May 2004. Citizens of these countries had full access to Ireland's labour market from the date of accession.
} 
In Table 2, we report the results from probit regressions in which the dependent variable is equal to one in the individuals reports that they received some form of training in 2005 and zero if not. Before looking at the immigrant coefficients, we will briefly consider the other coefficients to see if the models are producing results that are generally consistent with what would be expected.

Looking at Model 1 in Table 2, we can see that the pattern of results is essentially what would be expected based on the existing literature. Tenure and experience have a negative impact on training receipt; this is consistent with a human capital view which would see reduced pay-off periods as lowering the potential value of additional training. Full-time employees, members of professional bodies and union members are all shown to have a greater likelihood of receiving training. Similarly, employees in larger companies are also more likely to receive training.

Turning to the coefficient on the immigrant dummy, we see that it is negative and significant. In terms of a marginal impact, immigrants are 3 percent less likely to receive employer-provided training. While this result is interesting to a degree, earlier research on immigrants in Ireland has shown that the labour markets outcomes for different immigrant groups vary considerably ${ }^{5}$. For this reason, it is important to look separately at the different groups and we do this in Model 2. Once we do this we see the different outcomes emerging. The only coefficient that is significant across the five immigrant categories is that of the NMS countries. In addition, the marginal impact for this group, at 13 percent, is substantially higher than that estimated of immigrants as a whole. Of the other groups of immigrants, only those from nonEU/non-English-speaking countries appear to experience a lower incidence of employer-provided training relative to native workers. In Model 3, we add controls for occupation and sector to explore the possibility that our observations arise from a concentration of NMS immigrants in low-training occupations and sectors. While both the estimated coefficient and marginal impact for NMS immigrants fall when these controls are added, we are still observing a significant gap between natives and NMS immigrants in terms of receipt of employer-provided training. In the case of

\footnotetext{
${ }^{5}$ For example, see Barrett and McCarthy (2007) and Barrett et al (2008) on earnings and Barrett and Duffy (2008) on occupational attainment.
} 
immigrants from non-EU/non-English speaking countries, the estimated coefficient is no longer significant in Model 3.

Barrett et al (2008) demonstrate that observed wage impacts adjust significantly when account is taken of sample selection bias. Thus it seems, at least in respect to wages, some immigrant groupings are not randomly distributed in terms of their personal characteristics and, when account is taken of this, the observed immigrant wage penalty increases significantly. In the same vain, if it proves to be the case that immigrants possess characteristics that result in higher ex ante training probabilities, then failure to adjust for these influences will lead to some under-estimation of the immigrant training disadvantage.

Here, we account for selection effects by estimating matching models whereby the principal characteristics of immigrants are initially identified through a probit model. Immigrants are then matched on the basis of their predicted probabilities, or propensity scores, with natives holding similar characteristics and the training incidences of the two groups are then compared. In terms of the matching technique adopted, we apply Nearest Neighbour with replacement.

With respect to their dominant characteristics, immigrants were found to possess lower levels of tenure and labour market experience, more likely to hold postsecondary or post-graduate qualifications and were less likely to work in the public sector or be members of professional bodies or trade unions. Post matching analysis revealed that we were able to successfully match natives and immigrants on all key characteristics ${ }^{6}$.

The estimates generated by the matching process are presented in Table 3 . While some differences are apparent, most notably, no significant impact was found for nonEU / non-English speaking migrants. Generally speaking the results align well with those in Table 3 suggesting that selection bias is not an important factor in this regard.

\footnotetext{
${ }^{6}$ Results available from the authors.
} 
Barrett et al (2008) have shown how the wage disadvantage experienced by immigrants from the NMS countries in Ireland is not uniform across educational categories or across occupations. Instead, no disadvantage is present for immigrants with low levels of skills, as indicated by occupations and education levels, and is highest for those with higher levels of skill. Given this, it is of interest to explore whether the disadvantage in training for immigrants is similarly correlated with education and occupation.

In Table 4, we present the coefficients on immigrant dummy variables from regressions run within educational categories. The models are equivalent to Model 3 of Table 2, although with the education categories dropped. As can be seen, the training disadvantage is quite concentrated when viewed in this way, both in terms of nationalities and in terms of educational groups. Of the 25 nationality/education cells in Table 4, only three contain significant coefficients. Two of these relate to NMS immigrants. It appears that the training disadvantage is not present at either the lower and or highest ends of the education distribution but instead is concentrated around immigrants with post-secondary educations and primary degrees.

In Table 5, we present the coefficients from the analysis conducted within occupations. As with the education-base regressions, the training disadvantage is again seen to be concentrated. Looking specifically at NMS immigrants, we see how the disadvantage arises generally at towards the upper end of the occupational distribution, although not at the very top. This mirrors the results from the education analysis. However, there is also a clear training disadvantage for this group at the lowest end of the occupational ladder. We know from previous research (Barrett and Duffy, 2008) that NMS immigrants are often well educated but in low skill jobs. This pattern may explain the apparent discrepancy between the Tables 4 and 5, if NMS immigrants with post-secondary qualifications, for example, are working in elementary occupations.

We expand the analysis further in Tables 6, 7 and 8. In Table 6, Model 1, we include two sets of interactions between (a) the immigrant dummy variables and firm size and (b) the immigrant dummy variables and whether the immigrant is a union member. Before looking at the coefficients on the interactions, it should be noted that their 
inclusion has an impact on a number of the immigrant dummy coefficients. In Table 2 Model 3, only the immigrants from the NMS were found to experience a training disadvantage. However, in Table 6 Model 1, we now see that immigrants from the EU-13 and from non-EU-English-speaking countries also experience the disadvantage. In the case of both, we find significant interaction effects. Immigrants from both categories who work in large firms have higher likelihoods of receiving training relative to the base. It is possible that this positive effect arises from US and EU-13 nationals working in multinationals in Ireland. In contrast, there appears to be a penalty to union membership for these immigrants. In the case of the NMS immigrants, the inclusion of the interactions has no effect on the immigrant dummy coefficient and neither of the interaction terms is significant.

In model 2 and 3 of Table 6, we introduce a union-density variable which is a dummy variable equal to one if 50 percent of more of the employees in the firm are union members and zero otherwise. The inclusion of this variable is intended to capture the possible effect that a strong union presence in a firm might have on training provision generally and on immigrant in particular. As can be seen, the inclusion of this variable has little impact. The one exception to this is with regard to the interaction between immigrants from non-EU/non-English countries and the union density variable. This interaction term suggests a large and negative effect. One possible explanation would be the fact that the health service is both heavily unionised and a large employer of nationalities such as Filipinos (nurses) and Indians (doctors) ${ }^{7}$.

As a final extension of the analysis, we address the following questions: to what extent are immigrants less likely to be employed in training intensive firms and, secondly, are immigrants employed in training intensive firms less likely to receive employer-provided training than natives? We define a training intensive firm as one where 50 per cent or more employees received training in 2005. We then regress worker characteristics on this variable in order to identify those factors that most heavily influence an individual's likelihood of being employed in a training intensive firm, the results are presented in table 7 . The models are well specified and indicate that an individuals probability of being employed in a training intensive firm increases

\footnotetext{
${ }^{7}$ We should note that while these may be non-English speaking countries, the immigrants from them may well be good English speakers.
} 
with education with the results suggest that training intensive firms tend to be larger and have lower levels of trade-union density. Critically our models indicates that immigrants are indeed less likely to be employed in training intensive organisations with the disadvantage specific to immigrants from new member states and non-EU non English speaking countries.

In order to test the second hypothesis, we divide our sample of employees into two groups; those working training intensive firms and the rest. We then rerun the probit training regressions within each group. The results are shown in Table 8, with only the immigrant dummy coefficients presented. A number of striking results emerge. First, there is no training disadvantage for immigrants relative to natives if they are employed in training intensive firms. Indeed, in the case of immigrants from nonEU/English speaking countries there is actually a greater likelihood of training. In contrast, the training disadvantage of immigrants is apparent in the firms that are less intensive trainers. As with earlier tables, we see again the disadvantage experienced by immigrants from both the EU-13 and the NMS. However, these groups are now joined by immigrants from the UK.

\section{Section 5: Conclusions}

A number of findings have emerged from our analysis of the relative likelihood of immigrants and natives receiving employer-provided training. Our baseline analysis (Table 2, Model 3) showed that only immigrants from the EU’s New Member States suffered a training disadvantage. These results were robust to the influences of selection bias. Within this NMS group, the training disadvantage was experienced only by those with post secondary education and primary degrees. The inclusion of interactions terms between the immigrant dummy variables and the variables union membership, union density and firm size had essentially no impact on the NMS immigrant coefficient. However, when we divided the sample into employees and training intensive and non-intensive firms, not only were immigrants from NMS less likely to be employed in a training intensive firms, a further training disadvantage was experienced by this group employed in non-training intensive firms.

For other immigrants, a more mixed picture emerges with training disadvantages arising for very specific sub-groups. For example, immigrants from non-EU/English 
speaking countries working as process, plant and machine operatives were shown to be 26 percent less likely to receive training when compared to natives in the same occupations. Immigrants from the EU-13 were found to be 32 percent less likely to receive training relative to natives, once interactions were controlled for which picked up the effect of EU-13 immigrant working in large firms.

At one level, these results point to a labour market disadvantage facing immigrants from the NMS in particular. When combined with earlier findings on their lower levels of earnings and poorer occupational attainment, the findings here add to a set of poor labour market outcomes. But on a broader level, the findings also point to a diversity of experience both within the NMS immigrants and across other immigrant groups. Such diversity of outcomes is likely to be related in turn to a diversity of processes. In some cases, the lower rate of receipt of employer provided training may result from decisions on the part of immigrants while in other cases, the decisions of employers may be the key determinant. Clearly, much more needs to be done to gain a deeper understanding of the labour market outcomes of immigrants beyond the wellresearched areas of earnings and occupational attainment. 


\section{Tables}

Table 1: Raw Probabilities

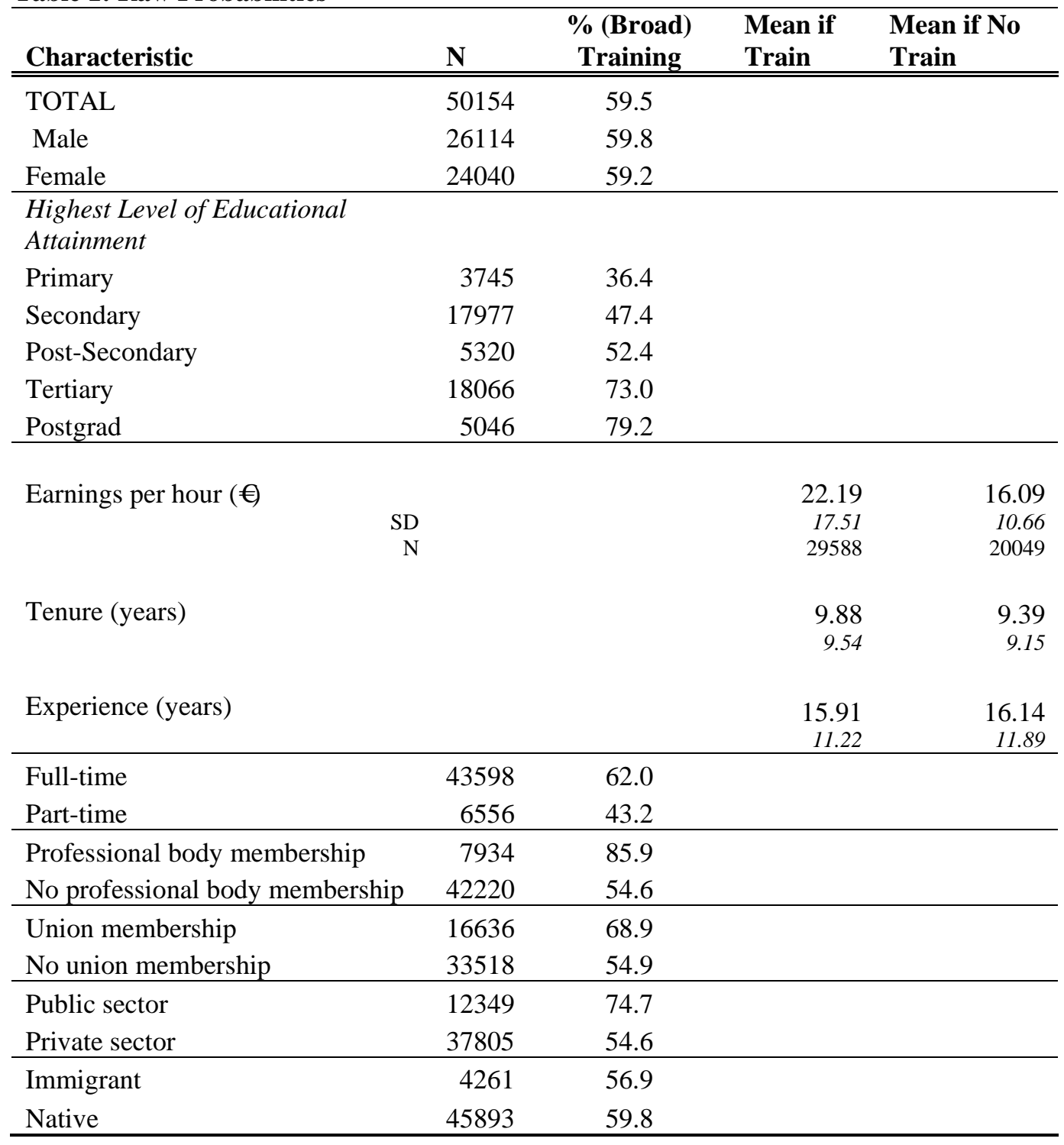


Table 2: Probit regressions, dependant variable: "broad” training

\begin{tabular}{|c|c|c|c|c|c|c|}
\hline & \multicolumn{2}{|c|}{ Model 1} & \multicolumn{2}{|c|}{ Model 2} & \multicolumn{2}{|c|}{ Model 3} \\
\hline \multirow{3}{*}{ Constant } & Coef. & $d F / d x$ & Coef. & $d F / d x$ & Coef. & $d F / d x$ \\
\hline & $-1.03 * * *$ & & $-1.02 * * *$ & & $-0.34 * * *$ & \\
\hline & 0.03 & & 0.03 & & 0.09 & \\
\hline \multirow{2}{*}{ Immigrant: } & $-0.11 * * *$ & & & & & \\
\hline & 0.02 & -0.03 & & & & \\
\hline \multirow{2}{*}{ UK } & & & -0.02 & & -0.01 & \\
\hline & & & 0.04 & -0.01 & 0.04 & -0.01 \\
\hline \multirow{2}{*}{ EU13 } & & & -0.07 & & -0.08 & \\
\hline & & & 0.05 & -0.03 & 0.06 & -0.03 \\
\hline \multirow{2}{*}{ NMS } & & & $-0.33 * * *$ & & $-0.23 * * *$ & \\
\hline & & & 0.05 & -0.13 & 0.05 & -0.09 \\
\hline \multirow{2}{*}{$\begin{array}{l}\text { Non-EU/English } \\
\text { Speaking }\end{array}$} & & & 0.09 & & 0.06 & \\
\hline & & & 0.08 & 0.03 & 0.08 & 0.02 \\
\hline \multirow{2}{*}{$\begin{array}{l}\text { Non-EU/Non- } \\
\text { English Speaking }\end{array}$} & & & $-0.12^{* * *}$ & & -0.04 & \\
\hline & & & 0.04 & -0.05 & 0.05 & -0.02 \\
\hline \multirow{2}{*}{ Tenure } & $-0.01 * * *$ & & $-0.01 * * *$ & & -0.01 & \\
\hline & 0.00 & -0.00 & 0.00 & -0.00 & 0.00 & -0.01 \\
\hline \multirow{2}{*}{ Supervisor } & $0.48 * * *$ & & $0.48 * * *$ & & $0.44 * * *$ & \\
\hline & 0.01 & 0.17 & 0.01 & 0.17 & 0.02 & 0.16 \\
\hline \multirow{2}{*}{ Secondary* } & $0.21 * * *$ & & $0.21 * * *$ & & $0.16 * * *$ & \\
\hline & 0.03 & 0.08 & 0.03 & 0.08 & 0.03 & 0.06 \\
\hline \multirow{2}{*}{ Postsec* } & $0.32 * * *$ & & $0.32 * * *$ & & $0.27 * * *$ & \\
\hline & 0.03 & 0.11 & 0.03 & 0.11 & 0.03 & 0.10 \\
\hline \multirow{2}{*}{ Tertiary* } & $0.61 * * *$ & & $0.61 * * *$ & & $0.44 * * *$ & \\
\hline & 0.03 & 0.22 & 0.03 & 0.22 & 0.03 & 0.16 \\
\hline \multirow{2}{*}{ Postgrad* } & $0.70 * * *$ & & $0.70 * * *$ & & $0.49 * * *$ & \\
\hline & 0.03 & 0.23 & 0.03 & 0.23 & 0.03 & 0.17 \\
\hline \multirow{2}{*}{ Experience } & $-0.01 * * *$ & & $-0.01 * * *$ & & $-0.01^{* * *}$ & \\
\hline & 0.00 & -0.00 & 0.00 & -0.00 & 0.00 & -0.00 \\
\hline \multirow{2}{*}{ Experience Sq } & $0.00 * *$ & & $0.00 * *$ & & $0.00 * * *$ & \\
\hline & 0.00 & 0.00 & 0.00 & 0.00 & 0.00 & 0.00 \\
\hline \multirow{2}{*}{ Full Time } & $0.26 * * *$ & & $0.26 * * *$ & & $0.23 * * *$ & \\
\hline & 0.02 & 0.10 & 0.02 & 0.10 & 0.02 & 0.09 \\
\hline \multirow{2}{*}{ Professional Body } & $0.54 * * *$ & & $0.54 * * *$ & & $0.46^{* * *}$ & \\
\hline & 0.02 & 0.19 & 0.02 & 0.19 & 0.02 & 0.16 \\
\hline \multirow{2}{*}{ Male } & $0.04 * * *$ & & $0.04 * * *$ & & $0.07 * * *$ & \\
\hline & 0.01 & 0.02 & 0.01 & 0.02 & 0.02 & 0.03 \\
\hline \multirow{2}{*}{ Union } & $0.18 * * *$ & & $0.18 * * *$ & & $0.18 * * *$ & \\
\hline & 0.02 & 0.07 & 0.02 & 0.07 & 0.02 & 0.07 \\
\hline Public Sector & 0.01 & & 0.01 & & $-0.40 * * *$ & \\
\hline & 0.02 & 0.01 & 0.02 & 0.01 & 0.03 & -0.15 \\
\hline Firm Size: & $0.12 * * *$ & & $0.12 * * *$ & & $0.12 * * *$ & \\
\hline $\ln (\mathrm{emp})$ & 0.00 & 0.05 & 0.00 & 0.05 & 0.00 & 0.05 \\
\hline Sector Controls & & & & & $X$ & \\
\hline Occupation & & & & & & \\
\hline Controls & & & & & $X$ & \\
\hline
\end{tabular}


N

Pseudo-R ${ }^{2}$

Observed

Probability

Predicted

Probability (at the mean)

\begin{tabular}{ccc}
49,420 & 49,420 & 49,420 \\
0.14 & 0.14 & 0.16 \\
0.60 & 0.60 & 0.60 \\
0.62 & 0.62 & 0.62 \\
\hline
\end{tabular}

Note: * implies significance at the 10\% level; ** implies 5\% and *** implies 1\% 
Table 3: PSM Estimates (Nearest Neighbour)

\begin{tabular}{|c|c|c|}
\hline Migrant & $\begin{array}{c}-0.04^{* * *} \\
0.01\end{array}$ & \\
\hline UK & & $\begin{array}{l}0.01 \\
0.01\end{array}$ \\
\hline EU13 & & $\begin{array}{c}-0.00 \\
0.02\end{array}$ \\
\hline NMS & & $\begin{array}{c}-0.13^{* * *} \\
0.03\end{array}$ \\
\hline Non-EU/English Speaking & & $\begin{array}{c}0.06^{*} \\
0.04\end{array}$ \\
\hline Non-EU/Non-English Speaking & & $\begin{array}{c}-0.03 \\
0.03\end{array}$ \\
\hline
\end{tabular}


Table 4: Probit regressions by education level, dependant variable: “broad” training

\begin{tabular}{|c|c|c|c|c|c|c|c|c|c|c|c|c|c|c|}
\hline & \multicolumn{2}{|c|}{ Primary } & i & \multicolumn{2}{|c|}{ Secondary } & 1 & \multicolumn{2}{|c|}{ Post-Secondary } & 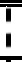 & \multicolumn{2}{|c|}{ Tertiary } & $\overline{1}$ & \multicolumn{2}{|c|}{ Postgraduate } \\
\hline \multirow{3}{*}{ UK } & Coef. & $d F / d x$ & 1 & Coef. & $d F / d x$ & I & Coef. & $d F / d x$ & I & Coef. & $d F / d x$ & 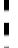 & Coef. & $d F / d x$ \\
\hline & 0.16 & & ! & -0.06 & & ! & 0.05 & & ! & 0.01 & & ! & -0.12 & \\
\hline & 0.15 & 0.06 & ! & 0.07 & -0.02 & ! & 0.10 & 0.02 & ! & 0.07 & 0.00 & ! & 0.11 & -0.03 \\
\hline \multirow{2}{*}{ EU13 } & -0.15 & & ; & $-0.32 * *$ & & ; & 0.10 & & ; & -0.13 & & ; & 0.18 & \\
\hline & 0.23 & -0.06 & 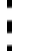 & 0.12 & -0.12 & 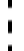 & 0.16 & 0.04 & 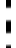 & 0.09 & -0.04 & 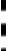 & 0.12 & 0.04 \\
\hline \multirow{2}{*}{ NMS } & -0.05 & & ! & -0.09 & & ! & $-0.33 * * *$ & & ! & $-0.31^{* * *}$ & & ! & -0.23 & \\
\hline & 0.18 & -0.02 & ! & 0.09 & -0.04 & $\begin{array}{c}1 \\
\vdots \\
\vdots\end{array}$ & 0.10 & -0.13 & ! & 0.09 & -0.11 & $\begin{array}{c}1 \\
\vdots \\
\vdots\end{array}$ & 0.17 & -0.07 \\
\hline \multirow[t]{2}{*}{ Non-EU/English Speaking } & 0.33 & & i & 0.18 & & i & -0.13 & & i & 0.00 & & i & 0.15 & \\
\hline & 0.52 & 0.13 & I & 0.16 & 0.07 & I & 0.28 & -0.05 & ! & 0.11 & 0.00 & ! & 0.20 & 0.04 \\
\hline \multirow{2}{*}{$\begin{array}{l}\text { Non-EU/Non-English } \\
\text { Speaking }\end{array}$} & 0.12 & & ! & -0.08 & & ; & 0.07 & & ! & -0.05 & & ; & 0.04 & \\
\hline & 0.15 & 0.05 & ! & 0.10 & -0.03 & ' & 0.15 & 0.03 & ' & 0.07 & -0.02 & ' & 0.14 & 0.01 \\
\hline $\mathrm{N}$ & \multicolumn{2}{|c|}{3,557} & I & \multicolumn{2}{|c|}{17,760} & ! & \multicolumn{2}{|c|}{5,229} & ; & \multicolumn{2}{|c|}{17,882} & 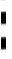 & \multicolumn{2}{|c|}{4,992} \\
\hline Pseudo- $\mathrm{R}^{2}$ & \multicolumn{2}{|c|}{0.08} & 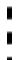 & \multicolumn{2}{|c|}{0.10} & ! & \multicolumn{2}{|c|}{0.1} & ! & \multicolumn{2}{|c|}{0.13} & 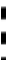 & \multicolumn{2}{|c|}{0.11} \\
\hline Observed Probability & \multicolumn{2}{|c|}{0.37} & I & \multicolumn{2}{|c|}{0.48} & 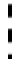 & \multicolumn{2}{|c|}{0.53} & ! & \multicolumn{2}{|c|}{0.73} & 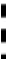 & \multicolumn{2}{|c|}{0.79} \\
\hline $\begin{array}{l}\text { Predicted Probability (at the } \\
\text { mean) }\end{array}$ & \multicolumn{2}{|c|}{0.36} & ! & \multicolumn{2}{|c|}{0.48} & $\begin{array}{c}1 \\
\vdots \\
\vdots\end{array}$ & 0. & & $\vdots$ & \multicolumn{2}{|c|}{0.76} & \begin{tabular}{c}
1 \\
$\vdots$ \\
$\vdots$ \\
\hdashline
\end{tabular} & \multicolumn{2}{|c|}{0.82} \\
\hline
\end{tabular}


Table 5: Probit regressions by occupation level, dependant variable: “broad” training

\begin{tabular}{|c|c|c|c|c|c|c|c|c|c|c|c|c|c|c|c|}
\hline \multirow[t]{2}{*}{ UKSOC } & \multicolumn{2}{|c|}{$\begin{array}{l}\text { Managers and } \\
\text { Senior Officials }\end{array}$} & \multicolumn{2}{|c|}{ : Professional } & \multicolumn{2}{|c|}{$\begin{array}{l}\text { Associate } \\
\text { Professional and } \\
\text { Technical } \\
\text { Occupations } \\
\end{array}$} & \multicolumn{2}{|c|}{$\begin{array}{l}\text { Administrative } \\
\text { and Secretarial } \\
\text { Occupations }\end{array}$} & \multicolumn{2}{|c|}{$\begin{array}{l}\text { Skilled Trades } \\
\text { Occupations } \\
\end{array}$} & \multicolumn{2}{|c|}{$\begin{array}{ll}\text { Personal } \\
\text { Service } \\
\text { Occupations }\end{array}$} & \multicolumn{2}{|c|}{$\begin{array}{l}\text { Sales and } \\
\text { Customer } \\
\text { Service } \\
\text { Occupations }\end{array}$} & ; \\
\hline & Coef. & $d F / d x$ & 'Coef. & $d F / d x$ & Coef. & $d F / d x$ & 'Coef. & $d F / d x$ & 'Coef. & $d F / d x$ & Coef. & $d F / d x$ & Coef. & $d F / d x$ & ! \\
\hline UK & $\begin{array}{l}-0.09 \\
0.11\end{array}$ & -0.03 & $\begin{array}{l}0.06 \\
0.09\end{array}$ & 0.02 & $\begin{array}{l}-0.11 \\
0.12\end{array}$ & -0.04 & $\begin{array}{l}0.07 \\
0.09\end{array}$ & 0.03 & $\begin{array}{l}-0.15 \\
0.16\end{array}$ & -0.06 & $\begin{array}{l}-0.07 \\
0.16\end{array}$ & -0.03 & $\begin{array}{l}-0.20 \\
0.28\end{array}$ & -0.08 & ; \\
\hline EU13 & $\begin{array}{l}0.41^{*} \\
0.22\end{array}$ & 0.11 & $\begin{array}{l}0.06 \\
0.12\end{array}$ & 0.02 & $\begin{array}{l}-0.65^{* * *} \\
0.15\end{array}$ & -0.23 & $\begin{array}{l}0.10 \\
0.11\end{array}$ & 0.04 & $\begin{array}{l}-0.39 \\
0.39\end{array}$ & -0.14 & $\begin{array}{l}0.04 \\
0.26\end{array}$ & 0.02 & $\begin{array}{l}-0.21 \\
0.28\end{array}$ & -0.08 & ! \\
\hline NMS & $\begin{array}{l}-0.38 \\
0.35\end{array}$ & -0.14 & $\begin{array}{l}-0.41^{* *} \\
0.20 \\
:\end{array}$ & -0.12 & $\begin{array}{l}-0.47^{*} \\
0.28\end{array}$ & -0.17 & $\begin{array}{l}-0.22 \\
0.16 \\
:\end{array}$ & -0.09 & $\begin{array}{l}-0.20 \\
0.13 \\
\vdots\end{array}$ & -0.07 & $\begin{array}{l}-0.07 \\
0.18\end{array}$ & -0.03 & $\begin{array}{l}-0.24 \\
0.19 \\
\end{array}$ & -0.09 & ! \\
\hline $\begin{array}{l}\text { Non-EU/English } \\
\text { Speaking }\end{array}$ & 0.32 & 0.09 & 0.04 & 0.01 & 0.18 & 0.05 & $\begin{array}{ll}0.16 \\
:\end{array}$ & 0.06 & $\begin{array}{ll}-0.04 \\
:\end{array}$ & -0.01 & -0.26 & -0.10 & 0.13 & 0.05 & ! \\
\hline & 0.29 & & 0.15 & & 0.23 & & 0.17 & & 0.45 & & 0.42 & & 0.36 & & ! \\
\hline $\begin{array}{l}\text { Non-EU/Non- } \\
\text { English Speaking }\end{array}$ & $\begin{array}{l}0.31 \\
0.32\end{array}$ & 0.09 & $\begin{array}{l}-0.28^{* *} \\
0.11\end{array}$ & -0.08 & $\begin{array}{l}-0.10 \\
0.15\end{array}$ & -0.03 & $\begin{array}{l}0.27 * \\
0.15\end{array}$ & 0.11 & $\begin{array}{l}-0.23 \\
0.17\end{array}$ & -0.09 & $\begin{array}{l}0.19 \\
0.13\end{array}$ & 0.07 & $\begin{array}{l}-0.01 \\
0.20\end{array}$ & -0.00 & \\
\hline $\mathrm{N}$ & 4,523 & & 10,529 & & : 4,787 & & 10,501 & & : 3,379 & & : 2,959 & & : 3,075 & & 1 \\
\hline Pseudo- $\mathrm{R}^{2}$ & 0.16 & & 0.10 & & 0.10 & & 0.16 & & 0.08 & & 0.11 & & 0.11 & & ; \\
\hline Observed & & & 1 & & 1 & & I & & & & & & 1 & & I \\
\hline Probability & 0.70 & & 0.81 & & 0.74 & & 0.53 & & 0.46 & & 0.53 & & 0.47 & & i \\
\hline Predi & & & 1 & & 1 & & 1 & & 1 & & I & & 1 & & ! \\
\hline Probability (at the & & & i & & 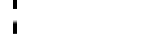 & & 1 & & & & & & $i$ & & I \\
\hline mean) & 0.74 & & 0.83 & & 0.76 & & 0.54 & & 0.45 & & 0.54 & & 0.47 & & \\
\hline
\end{tabular}


Table 5 continued: Probit regressions by occupation level, dependant variable: “broad” training

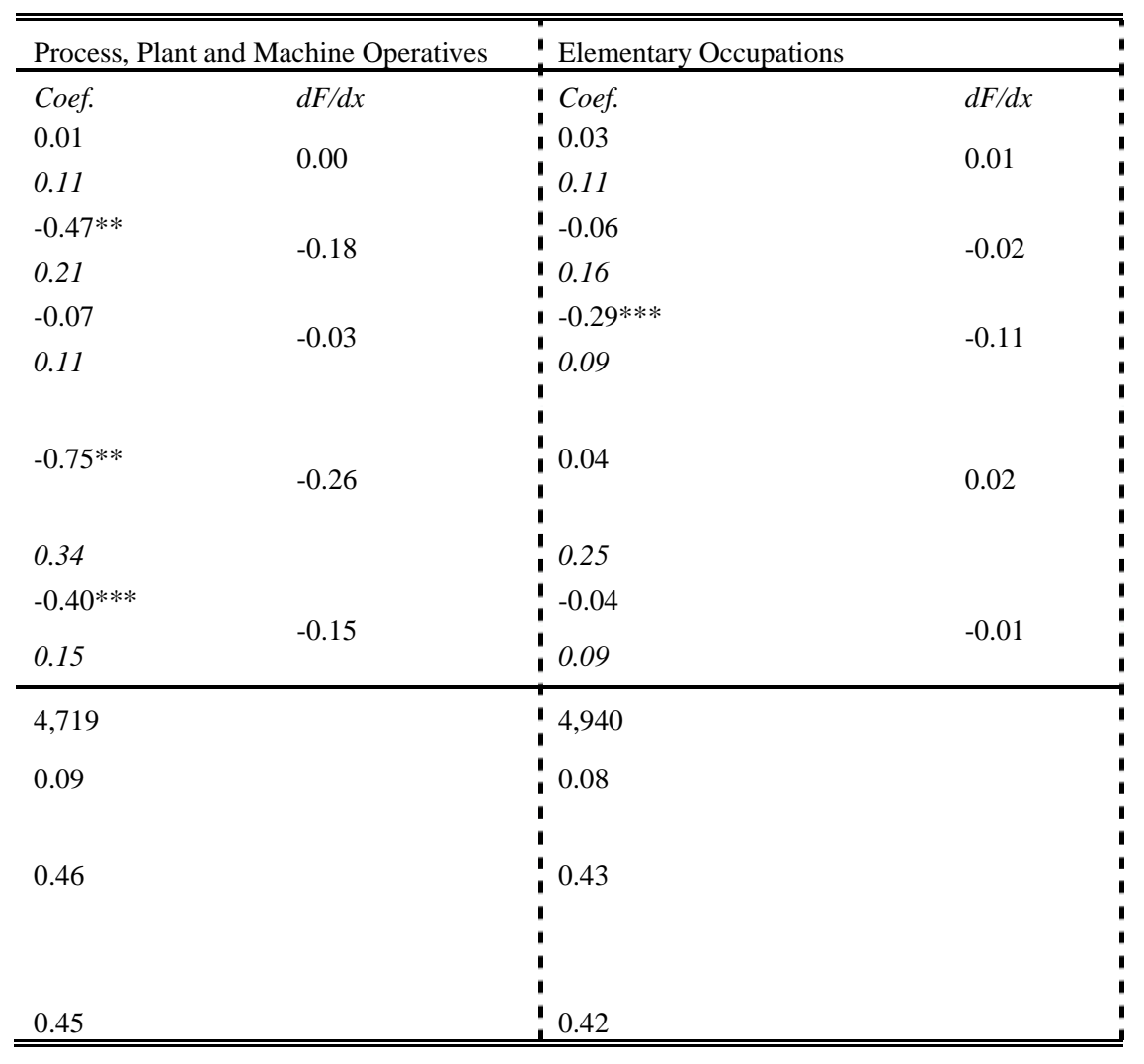


Table 6: Probit regressions with interactions, dependant variable: "broad" training

\begin{tabular}{|c|c|c|c|c|c|c|}
\hline & \multicolumn{2}{|c|}{ Model 1} & \multicolumn{2}{|c|}{ Model 2} & \multicolumn{2}{|c|}{ Model 3} \\
\hline Constant & $\begin{array}{c}\text { Coef. } \\
-1.02 * * * \\
0.05\end{array}$ & $d F / d x$ & $\begin{array}{c}\text { Coef. } \\
-0.34^{* * *} \\
0.09\end{array}$ & $d F / d x$ & $\begin{array}{c}\text { Coef. } \\
-0.34^{* * *} \\
0.09\end{array}$ & $d F / d x$ \\
\hline Immigrant: & & & & & & \\
\hline UK & $\begin{array}{c}-0.10 \\
0.09\end{array}$ & -0.04 & $\begin{array}{c}-0.01 \\
0.04\end{array}$ & -0.01 & $\begin{array}{c}-0.10 \\
0.10\end{array}$ & -0.04 \\
\hline EU13 & $\begin{array}{c}-0.83^{* * *} \\
0.15\end{array}$ & -0.32 & $\begin{array}{c}-0.08 \\
0.06\end{array}$ & -0.03 & $\begin{array}{c}-0.82^{* * *} \\
0.15\end{array}$ & -0.32 \\
\hline NMS & $\begin{array}{c}-0.29 * * \\
0.14\end{array}$ & -0.12 & $\begin{array}{c}-0.23 * * * \\
0.05\end{array}$ & -0.09 & $\begin{array}{c}-0.32 * * \\
0.14\end{array}$ & -0.12 \\
\hline $\begin{array}{l}\text { Non-EU/English } \\
\text { Speaking }\end{array}$ & $\begin{array}{c}-0.39 * \\
0.21\end{array}$ & -0.15 & $\begin{array}{l}0.06 \\
0.08\end{array}$ & 0.02 & $\begin{array}{c}-0.38 * \\
0.08\end{array}$ & -0.15 \\
\hline $\begin{array}{l}\text { Non-EU/Non-English } \\
\text { Speaking }\end{array}$ & $\begin{array}{c}0.06 \\
0.11\end{array}$ & 0.02 & $\begin{array}{c}-0.04 \\
0.05\end{array}$ & -0.02 & $\begin{array}{l}0.01 \\
0.12\end{array}$ & 0.02 \\
\hline Tenure & $\begin{array}{c}-0.01 \\
0.00\end{array}$ & -0.01 & $\begin{array}{c}-0.01 \\
0.00\end{array}$ & -0.01 & $\begin{array}{c}-0.01 \\
0.00\end{array}$ & -0.01 \\
\hline Supervisor & $\begin{array}{c}0.44^{* * *} \\
0.02\end{array}$ & 0.16 & $\begin{array}{c}0.44^{* * * *} \\
0.02\end{array}$ & 0.16 & $\begin{array}{c}0.44^{* * *} \\
0.02\end{array}$ & 0.16 \\
\hline Secondary* & $\begin{array}{l}0.17^{* * * *} \\
0.03\end{array}$ & 0.06 & $\begin{array}{c}0.16^{* * * *} \\
0.03\end{array}$ & 0.06 & $\begin{array}{c}0.16^{* * *} \\
0.03\end{array}$ & 0.06 \\
\hline Postsec* & $\begin{array}{l}0.27 * * * \\
0.03\end{array}$ & 0.10 & $\begin{array}{c}0.27 * * * \\
0.03\end{array}$ & 0.10 & $\begin{array}{c}0.27 * * * \\
0.03\end{array}$ & 0.10 \\
\hline Tertiary* & $\begin{array}{c}0.45^{* * * *} \\
0.03\end{array}$ & 0.16 & $\begin{array}{c}0.44^{* * * *} \\
0.03\end{array}$ & 0.16 & $\begin{array}{c}0.44^{* * *} \\
0.03\end{array}$ & 0.16 \\
\hline Postgrad* & $\begin{array}{c}0.49 * * * \\
0.03\end{array}$ & 0.17 & $\begin{array}{c}0.49 * * * \\
0.03\end{array}$ & 0.17 & $\begin{array}{c}0.49 * * * \\
0.03\end{array}$ & 0.17 \\
\hline Experience & $\begin{array}{c}-0.01^{* * * *} \\
0.00\end{array}$ & -0.00 & $\begin{array}{c}-0.01^{* * * *} \\
0.00\end{array}$ & -0.00 & $\begin{array}{c}-0.01^{* * *} \\
0.00\end{array}$ & -0.00 \\
\hline Experience Sq & $\begin{array}{l}0.00 * * * \\
0.00\end{array}$ & 0.00 & $\begin{array}{c}0.00 * * * \\
0.00\end{array}$ & 0.00 & $\begin{array}{c}0.00 * * * \\
0.00\end{array}$ & 0.00 \\
\hline Full Time & $\begin{array}{c}0.23^{* * * *} \\
0.02\end{array}$ & 0.09 & $\begin{array}{c}0.23 * * * \\
0.02\end{array}$ & 0.09 & $\begin{array}{c}0.23^{* * *} \\
0.02\end{array}$ & 0.09 \\
\hline Professional Body & $\begin{array}{c}0.46^{* * * *} \\
0.02\end{array}$ & 0.16 & $\begin{array}{c}0.46^{* * * *} \\
0.02\end{array}$ & 0.16 & $\begin{array}{c}0.46^{* * *} \\
0.02\end{array}$ & 0.16 \\
\hline Male & $\begin{array}{c}0.07 * * * \\
0.02\end{array}$ & 0.03 & $\begin{array}{c}0.07 * * * \\
0.02\end{array}$ & 0.03 & $\begin{array}{c}0.07 * * * \\
0.02\end{array}$ & 0.03 \\
\hline Union & $\begin{array}{c}0.20 * * * \\
0.02\end{array}$ & 0.07 & $\begin{array}{c}0.18 * * * \\
0.02\end{array}$ & 0.07 & $\begin{array}{c}0.18^{* * *} * \\
0.02\end{array}$ & 0.07 \\
\hline Public Sector & $\begin{array}{c}-0.39 * * * \\
0.03\end{array}$ & -0.15 & $\begin{array}{c}-0.40 * * * \\
0.03\end{array}$ & -0.16 & $\begin{array}{c}-0.40 * * * \\
0.03\end{array}$ & -0.15 \\
\hline Firm Size: $\ln (\mathrm{emp})$ & $\begin{array}{c}0.11^{* * *} \\
0.00\end{array}$ & 0.05 & $\begin{array}{c}0.12^{* * *} \\
0.00\end{array}$ & 0.05 & $\begin{array}{c}0.12^{* * *} \\
0.00\end{array}$ & 0.05 \\
\hline Trade Union Density & & & 0.01 & 0.01 & 0.02 & 0.01 \\
\hline
\end{tabular}




\begin{tabular}{|c|c|c|c|c|c|}
\hline \multirow{2}{*}{ INTERACTIONS } & \multirow{2}{*}{\multicolumn{3}{|c|}{0.02}} & \multicolumn{2}{|l|}{0.02} \\
\hline & & & & & \\
\hline UK*Firm size & -0.02 & -0.01 & & 0.02 & 0.01 \\
\hline \multirow[b]{2}{*}{ EU13*Firm size } & $\begin{array}{c}0.02 \\
0 . * *\end{array}$ & & & $\begin{array}{c}0.02 \\
017 * * *\end{array}$ & \\
\hline & 0.03 & 0.07 & & 0.03 & 0.07 \\
\hline \multirow{2}{*}{ NMS*Firm size } & 0.02 & 001 & & 0.03 & 001 \\
\hline & 0.03 & 0.01 & & 0.03 & 0.01 \\
\hline \multirow{2}{*}{$\begin{array}{l}\text { Non-EU/English } \\
\text { Speaking*Firm size }\end{array}$} & $0.12^{* *}$ & 0.04 & & $0.10^{* *}$ & 0.04 \\
\hline & 0.05 & & & 0.05 & \\
\hline \multirow{2}{*}{$\begin{array}{l}\text { Non-EU/Non-English } \\
\text { Speaking*Firm size }\end{array}$} & -0.01 & -0.00 & & 0.00 & 0.00 \\
\hline & 0.03 & & & 0.03 & \\
\hline \multirow[t]{2}{*}{ UK*TU member } & -0.00 & 0.00 & & & \\
\hline & 0.10 & & & & \\
\hline \multirow{2}{*}{ EU13*TU member } & $-0.47 * * *$ & -0.18 & & & \\
\hline & 0.18 & -0.10 & & & \\
\hline \multirow{2}{*}{ NMS*TU member } & 0.06 & בח 0 & & & \\
\hline & 0.18 & 0.02 & & & \\
\hline \multirow{2}{*}{$\begin{array}{c}\text { Non-EU/English } \\
\text { Speaking*TU member }\end{array}$} & $-0.41 * *$ & -0.16 & & & \\
\hline & 0.21 & & & & \\
\hline $\begin{array}{l}\text { Non-EU/Non-English } \\
\text { Speaking*TU member }\end{array}$ & & -0.20 & & & \\
\hline \multirow{2}{*}{ UK*TU density } & & & & 0.01 & 001 \\
\hline & & & & 0.10 & \\
\hline \multirow{2}{*}{ EU13*TU density } & & & & -0.21 & -0.08 \\
\hline & & & & 0.17 & \\
\hline \multirow{2}{*}{ NMS*TU density } & & & & -0.13 & -0.05 \\
\hline & & & & 0.18 & \\
\hline \multirow{2}{*}{$\begin{array}{l}\text { Non-EU/English } \\
\text { Speaking*TU density }\end{array}$} & & & & -0.18 & -0.07 \\
\hline & & & & 0.21 & \\
\hline \multirow{2}{*}{$\begin{array}{l}\text { Non-EU/Non-English } \\
\text { Speaking*TU density }\end{array}$} & & & & $-0.36 * *$ & -0.14 \\
\hline & & & & 0.14 & \\
\hline Sector Controls & $X$ & & $X$ & $X$ & \\
\hline Occupation Controls & $x$ & & $X$ & $X$ & \\
\hline $\mathrm{N}$ & \multicolumn{2}{|c|}{49,420} & 49,420 & \multicolumn{2}{|c|}{49,420} \\
\hline Pseudo- $\mathrm{R}^{2}$ & \multicolumn{2}{|c|}{0.16} & 0.16 & \multicolumn{2}{|c|}{0.16} \\
\hline Observed Probability & \multicolumn{2}{|c|}{0.60} & 0.60 & \multicolumn{2}{|c|}{0.60} \\
\hline $\begin{array}{l}\text { Predicted Probability } \\
\text { (at the mean) }\end{array}$ & \multicolumn{2}{|c|}{0.62} & 0.62 & \multicolumn{2}{|c|}{0.62} \\
\hline
\end{tabular}


Table 7: Probit for employment in training intensive firms

\begin{tabular}{|c|c|c|}
\hline & Model 1 & \\
\hline \multirow{3}{*}{ Constant } & Coef. & Coef. \\
\hline & $-0.94 * * *$ & $-0.93 * * *$ \\
\hline & 0.03 & 0.09 \\
\hline Immigrant: & $\begin{array}{l}-0.11^{* * *} \\
0.02\end{array}$ & \\
\hline \multirow{2}{*}{ UK } & & 0.02 \\
\hline & & 0.04 \\
\hline \multirow{2}{*}{ EU13 } & & $-0.09 *$ \\
\hline & & 0.06 \\
\hline \multirow{2}{*}{ NMS } & & $-0.29 * * *$ \\
\hline & & 0.05 \\
\hline \multirow{2}{*}{$\begin{array}{l}\text { Non-EU/English } \\
\text { Speaking }\end{array}$} & & 0.10 \\
\hline & & 0.09 \\
\hline \multirow{2}{*}{$\begin{array}{l}\text { Non-EU/Non-English } \\
\text { Speaking }\end{array}$} & & $-0.11^{* *}$ \\
\hline & & 0.05 \\
\hline \multirow{2}{*}{ Tenure } & $-0.01 * * *$ & $-0.01 * * *$ \\
\hline & 0.00 & 0.00 \\
\hline \multirow{2}{*}{ Supervisor } & $0.11^{* * *}$ & $0.11^{* * *}$ \\
\hline & 0.02 & 0.02 \\
\hline \multirow{2}{*}{ Secondary* } & $0.12^{* * *}$ & $0.12^{* * *}$ \\
\hline & 0.03 & 0.03 \\
\hline \multirow{2}{*}{ Postsec* } & $0.25 * * *$ & $0.25 * * *$ \\
\hline & 0.03 & 0.03 \\
\hline \multirow{2}{*}{ Tertiary* } & $0.42 * * *$ & $0.42 * * *$ \\
\hline & 0.03 & 0.03 \\
\hline \multirow{2}{*}{ Postgrad* } & $0.53 * * *$ & $0.54 * * *$ \\
\hline & 0.04 & 0.03 \\
\hline \multirow{2}{*}{ Experience } & -0.00 & $-0.00 * * *$ \\
\hline & 0.00 & 0.00 \\
\hline \multirow{2}{*}{ Experience Sq } & 0.00 & 0.00 \\
\hline & 0.00 & 0.00 \\
\hline \multirow{2}{*}{ Full Time } & $0.22 * * *$ & $0.22 * * *$ \\
\hline & 0.02 & 0.02 \\
\hline \multirow{2}{*}{ Professional Body } & $0.22 * * *$ & $0.22 * * *$ \\
\hline & 0.03 & 0.02 \\
\hline \multirow{2}{*}{ Male } & -0.02 & -0.02 \\
\hline & 0.02 & 0.02 \\
\hline \multirow{2}{*}{ Union } & $-0.07 * * *$ & $-0.07 * * *$ \\
\hline & 0.02 & 0.02 \\
\hline Public Sector & $-0.20 * * *$ & $-0.20 * * *$ \\
\hline Sector Controls & $0 . \ell^{4}$ & 0.04 \\
\hline EicoußSäziernlı(entpd)ls & $0.28 * * *$ & $0.28 * * *$ \\
\hline$N$ & & 49420 \\
\hline
\end{tabular}




$\begin{array}{cc}49420 & \\ 0.32 & 0.32\end{array}$

$\begin{array}{lll}\text { Pseudo-R }^{2} & 0.32 & 0.32\end{array}$ 
Table 8: Probit regressions for employees in training intensive and non-intensive firms, dependant variable:

"broad" training

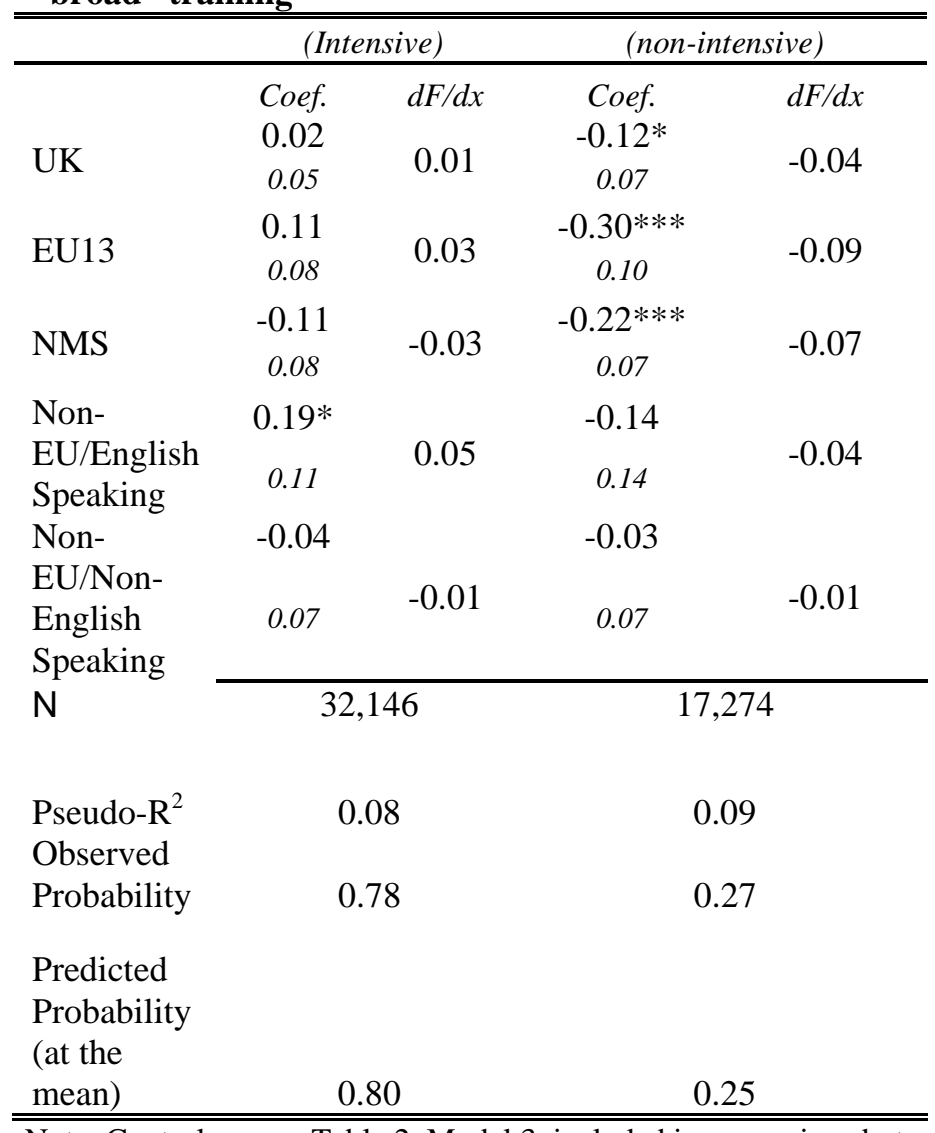

Note: Controls as per Table 2, Model 3, included in regressions but not reported 


\section{References}

Acemoglu D. and Pischke, J-S. (1999) "Beyond Becker: Training in Imperfect Labour Markets.” The Economic Journal, 109, F112-142.

Barrett, A. and D. Duffy, (2008), “Are Ireland's Immigrants Integrating into its Labour Market?”, International Migration Review Vol. 42 No. 3

Barrett, A. and Y. McCarthy (2007), "Immigrants in a Booming Economy: Analysing their Earnings and Welfare Dependence", Labour: Review of Labour Economics and Industrial Relations Vol. 21 No. 4-5

Barrett, Alan, Séamus McGuinness and Martin O’Brien (2008) “The Immigrant Earnings Disadvantage across the Earnings and Skills Distributions: The Case of Immigrants from the EU's New Member States in Ireland”, IZA Discussion Paper No. 3479

Becker, Gary S. (1964), Human Capital: A Theoretical and Empirical Analysis, with special Reference to Education, New York: National Bureau of Economic Research

Booth, A., Francesconi, M., and Zoega, G., (2003), "Unions, Work-related Training and Wages: Evidence for British Men.” Industrial and Labour Relations Review, Vol. 57, No. 1, Pp. 68-91.

Borjas, George J. (1985), "Integration, Changes in Cohort Quality and the Earnings of Immigrants”, Journal of Labor Economics Vol. 3 pp. 463-489

Chiswick, Barry R. (1978), "The Effect of Americanisation on the Earnings of Foreign-born Men”, Journal of Political Economy Vol. 86 pp. 897-921

Chiswick, Barry R., Yew Liang Lee and Paul Miller (2005), "Longitudinal Analysis of Immigrant Occupational Mobility: A Test of the Immigrant Integration Hypothesis”, International Migration Review Vol. 39 pp. 332-353

Doeringer, Peter B. and Michael J. Piore (1971), Internal Labor Markets and Manpower, Lexington, MA: Lexington Books

Gordon, D., Edwards, R., and Reich, M., (1982) Segmented Work, Divided Workers: The Historical Transformation of Labour in the United States. Cambridge, UK: Cambridge University Press.

Hum, Derek and Wayne Simpson (2003), “Job-related Training Activity by Immigrants to Canada”, Canadian Public Policy Vol. 29 No. 4 pp 469-490

Kennedy, S., R. Drago, J. Sloan and M. Wooden (1994) "The Effect of Trade Unions on the Provision of Training: Australian Evidence”, British Journal of Industrial Relations Vol. 32 No. 4 pp 565-560

Miller, Paul W. (1994), "Gender discrimination in Training: An Australian Perspective”, British Journal of Industrial Relations Vol. 32 No. 4 pp 539-564 
Mincer, Jacob (1974), Schooling, Experience, and Earnings, New York: National Bureau of Economic Research

O’Connell, P., and Junblut, J-M., (2008), "What do we Know about Training at Work?” in K.U. Mayer and H. Solga, (eds) Skill Formation: Interdisciplinary and Cross-National Perspectives. Cambridge, UK: Cambridge University Press.

Van den Heuvel, Audrey and Mark Wooden (1997), "Participation of non-EnglishSpeaking-Background Immigrants in Work-related Training”, Ethnic and Racial Studies Vol. 20 No. 4 pp 830-848 